\title{
Leptospirosis in dogs and cats: epidemiology, clinical disease, zoonotic implications and prevention
}

\author{
Leptospirosis en caninos y felinos domésticos: epidemiología, \\ enfermedad clínica, implicaciones zoonóticas y prevención \\ L Azócar-Aedo ${ }^{a}$, HL Smits ${ }^{\mathrm{b}}$, G Monti ${ }^{\mathrm{i}^{*}}$ \\ ${ }^{a}$ Becaria CONICYT, Programa de Doctorado en Ciencias Veterinarias, Facultad de Ciencias Veterinarias, \\ Universidad Austral de Chile, Valdivia, Chile. \\ ${ }^{b}$ KIT Biomedical Research, Royal Tropical Institute (KIT), Amsterdam, The Netherlands. \\ 'Instituto de Medicina Preventiva Veterinaria, Facultad de Ciencias Veterinarias, Universidad Austral de Chile, Valdivia, Chile.
}

\begin{abstract}
RESUMEN
La leptospirosis es una enfermedad zoonótica de distribución mundial causada por espiroquetas del género Leptospira. Este género incluye numerosos serovares que pueden ser eliminados en grandes cantidades en la orina de los animales infectados formando una importante fuente de infección. Muchas especies de mamíferos domésticos y silvestres son hospedadores de mantención constituyendo los reservorios de la bacteria y otras especies actúan como hospedadores incidentales que pueden desarrollar la enfermedad. En caninos y felinos la enfermedad es causada por diferentes serovares y los caninos actúan como hospedadores de mantención para algunos serovares y ambas especies son huéspedes incidentales para otros. Como perros y gatos pueden tener contacto frecuente con animales silvestres y de granja, constituyen una importante conexión en la transmisión. Las leptospiras pueden sobrevivir en el ambiente, lo que agrega complejidad a la epidemiología de la infección. La presentación de la enfermedad es muy variable y en particular la información sobre leptospirosis en felinos es limitada. Las pruebas de laboratorio son esenciales para el diagnóstico de la enfermedad, pero existen dificultades para discriminar entre la infección por Leptospira en pacientes con enfermedad clínica de la respuesta inmune específica de anticuerpos leptospirales tanto en los hospedadores de mantención como en animales con infección subclínica. La infección en mascotas puede tener importantes implicaciones económicas y de salud pública y debido al riesgo de transmisión de la enfermedad hacia los propietarios y otros animales, es necesario aplicar medidas de prevención.
\end{abstract}

Palabras clave: leptospirosis, perros, gatos, prevención.

\section{SUMMARY}

Leptospirosis is a zoonotic disease of worldwide distribution caused by spirochetes of the genus Leptospira. The genus includes a large number of serovars that may be sheed in the urine of infected animals creating a highly infectious source of transmission. Numerous species of wild and domestic mammals act as maintenance hosts and form reservoirs of the bacteria, with other species being incidental hosts that may develop the disease. In dogs and cats, the disease is caused by different serovars and while dogs act as maintenance host for some serovars, both species are incidental host for others. Dogs and cats may have frequent contact with wild and domestic farm animals, therefore they are an important link in the transmission route. Leptospira may survive in the environment which increases the complexity of the epidemiology. The presentation of the disease can be highly variable and, particularly for feline leptospirosis, not well described. Laboratory testing is essential for the diagnosis, however, it is complicated due to the need to discriminate between Leptospira infection in animals with clinical disease from leptospiral specific antibody responses in maintenance hosts, or in animals with subclinical infection. Infection in pets may have important economic and public health implications and because of the risk of transmission from pets to their owners and to other animals, preventive measures need to be applied and an increased awareness is adviced.

Key words: leptospirosis, dogs, cats, prevention.

\section{INTRODUCTION}

Zoonoses are infections of high relevance since most of the emerging infectious diseases in humans have a zoonotic origin (Paul-Pierre 2009). The increase in the presentation of emerging zoonotic diseases is a phenomenon closely linked to ecological, climatic and sociocultural changes

\footnotetext{
Accepted: 28.11.2013.

* gustavomonti@uach.cl
}

that have led animals and humans to share their habitats more frequently (Dabanch 2003). Among the zoonoses, leptospirosis has been reported as one of the most important conditions with sanitary, economic and social impacts worldwide (Parreira et al 2010).

Leptospirosis is a disease caused by infection with a motile spirochaetal bacterium of the genus Leptospira (Goldstein 2010). It is a systemic disease in dogs, cattle, swine, horses and humans (Adler and De la Peña Moctezuma 2010). The disease is probably is one of the most widespread zoonosis (Zavitsanou and Babatsikou 
2008) and is also recognised as a global public health problem (Vijayachari et al 2008).

Leptospirosis is often not recognised or misdiagnosed due to its variable presentation, therefore its incidence is likely to be underestimated and/or underreported. The World Health Organization classifies leptospirosis as a neglected tropical disease of global importance. Further research is needed to better understand the transmission dynamics and how these are influenced by climatic events, environmental factors, animal reservoirs, demographic, social and human trends (Lau et al 2010). Comprehensive understanding of its eco-epidemiological characteristics is the essential prerequisite to take effective and acceptable control measures (Vijayachari et al 2008).

The aim of this article is to review the main features of leptospirosis in domestic dogs and cats considering basic characteristics of the bacteria, to describe aspects on epidemiology, clinical signs and diagnosis, to highlight the potential zoonotic implications of the infection from pets to their owners and to revise some topics on prevention.

\section{LEPTOSPIRES AND LEPTOSPIROSIS}

The genus Leptospira belongs to the family Leptospiraceae, order Spirochaetales (Adler and De la Peña Moctezuma 2010). This genus is composed by a varied group of organisms which can live in diverse environments, habitats and life cycles. Within the genus, highly pathogenic host-specific strains can be found, harmless free-living waterborne strains. The genus is divided in about 20 species based on DNA hybridization studies (Barthi et al 2003). They can be classified in 3 groups as follows (Cerqueira and Picardeau 2009):

- Pathogens group: L. interrogans, L. kirshneri, L. noguchii, L. borgpetersenii, L. weilii, L. santarosai, $L$. alexanderi, L. alstonii (Genomospecies1).

- Intermediates group: L. wolffii, L. licerasiae, L. inadai, L. fainei, L. broomii.

- Non-pathogenic group: L. kmetyi, L. wolbachii, L. meyeri, L. biflexa, L. vanthielii (Genomospecies 3), L. terpstrae (Genomospecies 4), L. yanagawae (Genomospecies 5).

According to the above classification, the pathogenic group includes Leptospira strains isolated from humans or animals. The intermediate species are distinct from pathogens and non-pathogenic strains according to their rRNA $16 \mathrm{~S}$ sequence, and their virulence has not been demonstrated experimentally. On the other hand, the non-pathogenic or saprophitic species are environmental strains (Picardeau 2013).

The genus Leptospira is serologically classified into serovars and it includes more than two hundred pathogenic serovars, based on the structural heterogeneity of the bacterial lipopolysaccharide (Xue et al 2009). Serogroups comprise antigenically related serovars. For pathogenic strains, about 24 serogroups have been described (Picardeau 2013).

Leptospires are highly motile, obligate aerobic bacteria measuring about 0.25 by 6 to $25 \mu \mathrm{m}$ (Bharti et al 2003). The cells have pointed ends, either or both of which are usually shaped into a distinctive hook and have a typical double membrane structure in which the cytoplasmic membrane and peptidoglycan cell wall are closely associated by an outer membrane (Levett 2001). These bacteria have an optimum growth temperature of 28 to $30^{\circ} \mathrm{C}$ (Bharti et al 2003) and can survive up to 180 days in moist soil, and for several months in aqueous surfaces. Especially stagnant or slow-moving water provide and excellent habitat for them. Survival in the environment is inhibited by contamination with sewage, high acidity and high salinity. The optimum $\mathrm{pH}$ range for the survival of Leptospira is 6.2 to 8.0 (Guerra 2009). Pathogenic leptospires do not multiply outside the host, therefore, to produce an outbreak of leptospirosis is necessary the presence of carrier animals and favorable conditions for the survival of the bacteria in the environment (Acha and Szyfres 2003).

Leptospira serovars are maintained in the environment by a wide variety of domestic and wildlife animal species, which acts as reservoirs of the bacterium and are called "primary reservoir hosts" (Greene et al 2008). Mammals are the only animals capable of transmitting the bacteria, even though they have also been identified in reptiles and birds (Guerra 2009).

In the primary reservoir hosts, kidney colonization occurs because the bacterium persist in the kidney tubular epithelial cells (Sessions and Greene 2004 a). This infection is normally characterised by the presence of a low antibody response, mild acute clinical signs of disease and a prolonged kidney carrier state which could be associated with chronic renal disease (Bolin 1996). These hosts can shed the bacterium in the urine for months (intermittently) or throughout their life, leading to the direct or indirect infection of other animals or humans (Van de Maele et al 2008). The most important primary reservoir host are small feral mammals (Levett 2004).

Leptospira serovars demonstrated specific but not exclusive host preferences (Ko et al 2009). Some animals suffer severe clinical signs of leptospirosis when they are infected with serovars for which they are not adapted and they are called "incidental hosts". In these species the infection is associated with high antibody titres and a short or negligible renal carrier state (Bolin 1996, Guerra 2009). The transmission of the infection from an incidental host to another animal of the same species is relatively uncommon (Bolin 1996). An individual may act as primary reservoir for one serovar but incidental host for others (Levett 2004). Moreover, in humans the infection is always incidental. Some maintenance or primary reservoirs and incidental hosts of common serovars of Leptospira interrogans that infect dogs, cats and other animals have been mentioned by Greene et al (2008) and are summarised in table 1. 
Table 1. Some Leptospira interrogans serovars and their respective primary reservoir(s) and incidental hosts (Greene et al 2008)* Algunos serovares de Leptospira interrogans y sus respectivos hospedadores primarios e incidentales (Greene et al 2008)*

\begin{tabular}{|c|c|c|}
\hline Serovar & Primary reservoir hosts & Incidental hosts \\
\hline Hardjo & Cows & Dogs, humans, horses, pigs, sheeps, wild bovidae \\
\hline Pomona & Cows, pigs, skunks, opossums & $\begin{array}{l}\text { Dogs, cats, humans, horses, sheeps, goats, rabbits, mouses, } \\
\text { raccoons, wolves, foxes }\end{array}$ \\
\hline Canicola & Dogs & $\begin{array}{l}\text { Dogs, cats, humans, cows, horses, pigs, rats, raccoons, } \\
\text { armadillos, mongooses, otters, skunks }\end{array}$ \\
\hline Icterohaemorragiae & Rats & $\begin{array}{l}\text { Dogs, cats, humans, cows, horses, pigs, mouses, raccoons, } \\
\text { opossums, foxes, woodchucks, skunks }\end{array}$ \\
\hline Autumnalis & Mouses & Dogs, humans, cows, rats, raccoons, opossums \\
\hline Bratislava & Rats, pigs, horses & $\begin{array}{l}\text { Dogs, humans, cows, horses, mouses, foxes, voles, raccoons, } \\
\text { opossums, skunks, weasels }\end{array}$ \\
\hline Bataviae & Dogs, rats, mouses & Dogs, cats, humans, cows, hedgehogs, voles, armadillos, shrews \\
\hline
\end{tabular}

* Reprinted from Greene C, J Sykes, C Brown, K Hartmann. 2008. Leptospirosis. In: Greene C (ed). Enfermedades infecciosas del perro y el gato. Intermédica, Buenos Aires, Argentina. Copyright Elsevier.

Some serovars have worldwide distribution, while others have a more limited geographical spread (Miller et al 2007). Leptospirosis is especially prevalent in geographic areas with large annual rainfall and warm climate, however factors such as host exposure and the presence of wild and domestic reservoir also influence the geographical distribution of the bacterium (Sykes et al 2011). The disease tends to be seasonal in temperate climates and year-round in tropical climates. Outbreaks often increase after periods of flooding or increased rainfall. In arid areas or during drought conditions, infections in incidental hosts are more common around water sources (Langston and Heuter 2003).

Each geographic area is characterised by the serotypes (serogroups, serovars) determined by the ecology of the area (Acha and Szyfres 2003), and both the prevalence of the disease and distribution of serovars vary between different countries, and even between regions within a country. Human cases are more prevalent in the Caribbean and Latin America, the Indian Subcontinent, Southeast Asia, Oceania and to a lesser extent Eastern Europe (Sykes et al 2011). In Chile, the infection is widespread among domestic animals, especially in the south of the country, where annually it causes extensive losses, for example in cattle, due to reproductive failures (Riedemann and Zamora 1987).

The transmission of the Leptospira infection occurs by contact of intact mucous membranes or abraded skin with infected urine or urine-contaminated soil, water, food and also after bite-wound inoculation or ingestion of infected tissues (Sykes et al 2011). Pets may become exposed to leptospires excreted by urine of wild or farm animals through activities such as swimming, drinking or walking through contaminated water, soil and mud (Brown and Prescott 2008). The degree of transmission of the infection depends on climate, population density and contact rates between incidental and maintenance hosts (Levett 2001).

\section{LEPTOSPIROSIS IN DOGS}

Historically, leptospirosis was recognised as a disease of dogs before it was know in any other animal species, including humans (Faine 1994). It was first described in 1899 (Goldstein 2010). In 1931, Klarenbeek and Schuffner isolated leptospires from the urine of a dog affecting with nephritis in The Netherlands. The leptospiral strain was designed as "Leptospira canicola". This leptospiral serotype was isolated from dogs in the United States in 1937 (Levett 2001).

In dogs, about 10 different serovars have been serologically associated with clinical disease (Gautam et al $2010^{\mathrm{b}}$ ) and the most frequently described are Canicola, Icterohaemorragiae, Pomona, Bratislava and Grippotyphosa (Sessions and Greene 2004a). However, recent serological evidence, demonstrated a change in the predominant serovars implicated in canine infections, for example in USA and Canada (Goldstein et al 2006). This change has been attributed to widespread use of bivalent Leptospira vacines introduced in the 1960s, as well as the increased contact between dogs and wildlife reservoirs in expanding suburban environments (Stokes et al 2007). Dogs are considered as the primary reservoirs of the Leptospira interrogans serovars Canicola and Bataviae (Sessions and Greene 2004 ${ }^{\mathrm{a}}$ ). Some of the Leptospira serovars found in canines, in cross-sectional surveys carried out in different countries worldwide, are listed in the table 2.

Male dogs are more likely to develop leptospirosis than females, probably due to their natural straying behavior. Herding or hunting dogs are at greater risk of becoming infected than dogs kept only as pets. Furthermore, dogs that are exercised by walking in parks and those who wander in fields (for example, hound dogs) or with access to water sources where they swim have a higher risk of exposure to the bacteria. Besides, dogs living in suburban or urban 
Table 2. Prevalence of Leptospira infection and frequently reported serovars in dogs in cross-sectional studies carried out in some countries.

Prevalencia de la infección por Leptospira y serovares frecuentemente reportados en perros en estudios transversales realizados en algunos países.

\begin{tabular}{|c|c|c|c|c|c|c|}
\hline \multirow{2}{*}{ Author(s) } & \multirow{2}{*}{ Country } & \multirow{2}{*}{ City/ Region } & \multirow{2}{*}{$\begin{array}{c}\text { Sample } \\
\text { size }\end{array}$} & \multicolumn{2}{|c|}{ No. positive Prevalence } & \multirow{2}{*}{ Most frequent serovars } \\
\hline & & & & dogs* & $(\%)$ & \\
\hline Ambily et al (2012) & India & Kerala & 205 & 146 & 71.1 & $\begin{array}{l}\text { Autumnalis, Pomona, } \\
\text { Grippotyphosa, Canicola, } \\
\text { Pyrogenes, Icterohaemorragiae }\end{array}$ \\
\hline Aslantas et al (2005) & Turkey & Ankara & 116 & 51 & 43.9 & Canicola, Bratislava \\
\hline Batista et al (2004) & Brazil & Paraiba & 130 & 26 & 20.0 & $\begin{array}{l}\text { Pomona, Autumnalis, } \\
\text { Grippotyphosa, Patoc }\end{array}$ \\
\hline Burriel et al (2005) & Greece & NA & 254 & 29 & 11.4 & $\begin{array}{l}\text { Canicola, Icterohaemorragiae, } \\
\text { Copenhageni, Australis, Bratislava }\end{array}$ \\
\hline Fonzar and Langoni (2012) & Brazil & Maringá & 335 & 41 & 12.2 & $\begin{array}{l}\text { Pyrogenes, Canicola, } \\
\text { Copenhageni }\end{array}$ \\
\hline Gautam et al $2010^{\mathrm{a}}$ & USA & NA & 33,119 & 2.680 & 8.1 & $\begin{array}{l}\text { Pomona, Autumnalis, } \\
\text { Grippotyphosa, Bratislava }\end{array}$ \\
\hline Higgins and Cayouet (1978) & Canada & Quebec & 60 & 4 & 6.6 & Icterohaemorragiae \\
\hline Meeyam et al (2006) & Thailand & Chiang Mai & 210 & 23 & 11.0 & $\begin{array}{l}\text { Canicola, Icterohaemorragiae, } \\
\text { Bataviae, Australis }\end{array}$ \\
\hline O'Keefe et al (2002) & New Zealand & $\ldots$ & 433 & 41 & 14.2 & Canicola, Grippotyphosa \\
\hline Rad et al (2004) & Iran & Theran & 300 & 93 & 31.0 & $\begin{array}{l}\text { Canicola, Icterohaemorragiae, } \\
\text { Grippotyphosa }\end{array}$ \\
\hline Ribeiro de Castro et al (2011) & Brazil & Uberlandia & 268 & 76 & 28.4 & $\begin{array}{l}\text { Canicola, Autumnalis, } \\
\text { Gripptyphosa Tarassovi }\end{array}$ \\
\hline Rodríguez et al (2004) & Colombia & Cali & 197 & 81 & 41.1 & $\begin{array}{l}\text { Hardjo, Canicola, } \\
\text { Icterohaemorragiae, } \\
\text { Grippotyphosa }\end{array}$ \\
\hline Roach et al (2010) & South Africa & Coastal regions & 530 & 25 & 4.7 & Canicola, Pyrogenes \\
\hline Shi et al (2012) & China & Southern China & 314 & 23 & 7.3 & NA \\
\hline Stokes et al (2007) & USA & Michigan & 1241 & 463 & 24.9 & $\begin{array}{l}\text { Pomona, Canicola, Grippotyphosa, } \\
\text { Icterohaemorragiae, Bratislava }\end{array}$ \\
\hline
\end{tabular}

* The diagnostic test used in all studies was the MAT, except for the survey of Shi et al (2012) in which ELISA was used.

settings may also be at risk because of the presence of wildlife reservoir hosts (Gautam et al 2010 ${ }^{\mathrm{b}}$ ).

Stray dogs that roam free in cities are especially important in the transmission of infection (Batista et al 2004, Sontas et al 2012) because of the potential contact with infected canines or rodents. Rural areas has been demonstrated to pose a higher risk of infection because these environments tend to have larger concentrations of reservoirs such as livestock, rodents and small mammals and the contact with the dogs could make possible the infection (Ghneim et al 2007).

Leptospirosis continues to have a significant presence in canine medicine (Ananda et al 2008). The disease can be fatal for some dogs, but many cases are thought to be subclinical (Iwamoto et al 2009). Despite this situation, it is noted that the prevalence may be underestimated with a high rate of misdiagnosis, because the disease is not often included in the differential diagnosis of kidney diseases or because the owners do not seek veterinary assistance
(McDonough 2001). The results of cross-sectional surveys of Leptospira infection in dogs worldwide and in Chile are described in the tables 2 and 3, respectively.

Regarding the pathogenesis of the disease in dogs, after a variable incubation period, leptospires circulate in the blood before entering in many organs including the kidney, liver, spleen, reproductive tract, eyes and central nervous system, where they replicate (Bolin 1996). The primary lesion of leptospirosis is damage to the endothelium of small blood vessels that leads to localized ischemia and alterations in the different organs, such as renal tubular necrosis, hepatocellular and pulmonary damage and myositis (Adler and De la Peña Moctezuma 2010).

The incubation period of canine leptospirosis is about 5 to 15 days (Van de Maele et al 2008). The severity of clinical signs depends on the age and immune-competence of the animal, the serovar involved and the virulence of the bacteria. The disease can be presented as peracute, acute, subacute or chronic (Langton and Heuter 2003). However, 
Table 3. Prevalence of Leptospira infection and frequently reported serovars in dogs in published cross-sectional studies carried out in Chile.

Prevalencia de la infección por Leptospira y serovares frecuentemente reportados en perros en estudios transversales realizados en Chile y publicados.

\begin{tabular}{lcrrrr}
\hline \multirow{2}{*}{ Author(s) } & \multirow{2}{*}{ City } & \multicolumn{2}{c}{ Sample } & No. positive Prevalence & \multirow{2}{*}{ Most frequent serovars } \\
\cline { 3 - 5 } & & size & $\operatorname{dog} s^{* *}$ & $(\%)$ & \\
\hline Pineda et al (1966) & Chillán & 60 & 23 & 38.3 & Canicola, Sejroe \\
Silva and Riedemann (2007) & Valdivia & 400 & 59 & 14.8 & Canicola, Ballum, Icterohaemorragiae \\
\hline
\end{tabular}

* In Chile there are various cross-sectional studies of leptospirosis in dogs, but few are published.

** The diagnostic test used in both studies was the MAT.

most of the infections produce no pathognomonic signs (Silva and Riedemann 2007).

In the peracute presentation the leptospiremia leads to a rapid and progressive deterioration of health status. Acute leptospirosis is characterised by fever, vomiting, dehydration, tachypnoea and shock which can occur so quickly that hepatic or renal failure do not have time to develop (Van de Maele et al 2008); this form is known as Stuttgart disease (Faine 1994). Subacute leptospirosis is the most diagnosed form and the clinical signs included fever, anorexia, vomiting, dehydration, lethargy, muscle pain, diarrhea, compromised coagulation due to liver involvement or vasculitis that may lead to petechiae and/or ecchymoses. Eventually, chronic haepatitis may develop causing icterus, hepatic encephalopathy and weight loss. Coughing and dyspnoea may also occur with conjunctivitis, rhinitis and tonsilitis. Polyuria and polydipsia can appear as a result of progressive deterioration of renal function and/or liver insufficiency (Van de Maele et al 2008). Dogs with chronic leptospirosis could have chronic hepatitis or hepatic fibrosis and signs include anorexia, weight loss, ascites, hepatic encephalopathy and icterus (Andre-Fontaine and Hernandez 2008).

The findings in complete blood count of infected dogs may include neutrophilia, sometimes with a left shift, lymphopenia and mild to moderate non-regenerative anemia. Thrombocytopenia is present in up to $58 \%$ of affected dogs and if accompanied by evidence of acute kidney damage with or without hepatic injury, it can help to raise suspicion of leptospirosis. An increased serum urea and creatinine may be present in more than $80-90 \%$ of the dogs. Hepatic dysfunction may be manifested by increased activities of the enzymes alanine aminotransferase, aspartate aminotransferase, alkaline phosphatase and total bilirubin concentration, almost always associated to azotemia. An increase in serum creatine kinase activity may also be present, presumably due to myositis (Sykes et al 2011).

Studies have suggested some correlation between clinical aspects of the disease and the infecting serovar. For example in USA, a group of dogs with suspected infection with serovar Pomona diagnosed with the MAT (Microscopic Agglutination Test) were more likely to suffer from vomiting, trombocytopenia, azotemia and hyperphosphatemia than dogs infected with other serogroup. However, the relationship between infecting serovar and clinical disease requires further research (Goldstein et al 2006).

In clinical practice, dogs that develop signs of acute renal failure and/or icterus should be considered as suspected cases of leptospirosis until there is a definitive diagnosis (Van de Maele et al 2008), particularly if they have a history of absence of vaccination and a possible exposure to the bacteria. Nevertheless, specific diagnostic testing is required to confirm or rule out the diagnosis of leptospirosis (Bolin 1996). These methods include the detection of specific antibodies by the MAT and Enzyme Linked Immunoabsorbent Assay (ELISA) (Iwamoto et al 2009). Other techniques available for the diagnosis of leptospirosis in companion animals include darkfield microscopy observation, fluorescent antibody testing, histopathology, bacteriological culture and Polymerase Chain Reaction (PCR) (Bolin 1996).

Regarding the immune response for leptospirosis, the appearance of circulating antibodies coincides with the elimination of the circulating live leptospires from the blood and most organs (Bolin 1996). In natural infections, IgM titres rise within 1 week of infection and peak at 14 days after infection, whereas IgG titres are not present until 2 to 3 weeks after infection and peak at 1 month post infection (Langston and Heuter 2003).

The MAT remains the standard serological test for canine leptospirosis (Sessions and Greene 2004 ${ }^{\mathrm{a}}$ ). This test provides an estimate of the antibody titre against leptospires present in the serum of the patient. Serial dilutions of the serum of the dog are mixed with live/viable Leptospira strains of different serovars and darkfield microscopy is used to determine whether agglutination occurs (Van de Maele et al 2008). The antigen collection includes strains representative of the main serogroups and thus, the test is a specific serogroup method, non serovar specific (Picardeau 2013). The MAT panel for canine leptospirosis should include serovars known to be circulating in the local dog population (Sykes et al 2011).

Positive titres to MAT confirm the exposure of the animal to the bacteria. However, there no consensus about the 
definitive diagnostic titre. With a consistent clinical disease and vaccination of longer than 3 months, an antibody titre of 1:800 to $1: 1600$ in a single sample is a good presumptive evidence of leptospiral infection (Bolin 1996). However, there is a lack of large studies providing evidence for this threshold and the use of paired serum samples collected at different stages of the infection is prefered. Golstein (2010) noted that a 4-fold change in a convalescent titre compared with a baseline titre is consistent with an active infection. The MAT has the following disadvantages: a) It needs facilities for culturing and maintaining live leptospires; b) The method is technically demanding and time-consuming and c) Antibodies may not be detected when the causative strain is not represented in the panel or only low titres are found with a serovar that antigenically resembles the causative serovar (Safiullah et al 2009).

ELISA tests have been used to detect IgM or IgG antibodies to leptospires (Sessions and Greene 2004 ${ }^{\mathrm{a}}$ ). Conventional microtitre plate and dot-ELISA can detect IgM antibodies (Safiullah et al 2009). IgM antibodies become detectable during the first week of illness and their detection by ELISA can be more sensitive than MAT when the sample is taken early in the acute phase of illness (Levett 2004). These assays are sensitive, specific and are useful as serological screening tests because of their relative simplicity in comparison to MAT (WHO 2006). However, the disadvantage is that only a single genus-specific antigen is used and it does not give an indication of the infecting serovar (Safiullah et al 2009)

Some examples of rapid leptospirosis antibody-based tests are IgM ELISAs, IgM dipsticks and lateral flow assays. Rapid diagnostic assays must be accurate, user-friendly, relatively inexpensive, easy to interpret and stable under extreme conditions. However most of the commercially available and in-house tests for leptospirosis have no validation of their diagnostic performance and some present variable results depending of the country or geographic region that hampers their selection as tests of choice (Picardeau et al 2013).

Direct identification on darkfield microscopy has been used as a rapid screening test to identify leptospires in the urine of dogs (Bolin 1996) but it is no longer recommended because of its technical difficulty and low specificity. To detect an active infection, $10^{5}$ organism $/ \mathrm{mL}$ of urine are required (Sessions and Greene 2004 ${ }^{\mathrm{a}}$ ). The main problem is that the presence of other bacteria, detritus or artefacts in the sample can be confused with leptospires, conducting to false positive and false negative results. For this reason, the test only adds preliminary evidence of leptospiral infection, but the diagnosis must be confirmed by other methods (Langston and Heuter 2003).

Fluorescent antibody testing can be performed in urine, blood and histologic samples (Harkin et al 2003 ${ }^{\mathrm{a}}$ ) and it generally does not distinguish between serovars (Langston and Heuter 2003). Leptospires may also be detected by histopathological examination in tissues using silver or immunohistochemical stains (Levett 2004), but the infecting serovar cannot be determined (Bolin 1996).

Direct culture of the organism from blood or urine samples is the gold standard for the diagnosis of leptospirosis (Goldstein 2010). It is a low-yield procedure due to the difficulty in culturing the organism (Harkin et al 2003 ${ }^{\mathrm{a}}$ ). It requires a special medium and incubation for up to 3 to 6 months. Consequently, this method is not useful for early diagnosis (Sykes et al 2011).

PCR tends to replace serological methods because of its sensitivity and capacity to give an early diagnosis of leptospirosis (Picardeau 2013). Conventional and real-time assays have been developed and although this test has been designed to detect pathogenic serovars only, currently available assays do not differentiate between serovars and serogroups (Sykes et al 2011). During the acute phase of infection, PCR could be used for detecting Leptospira from blood samples; in contrast, in chronic cases or the late stage of acute disease, Leptospira can be detected in urine, liver and kidney biopsies (André-Fontaine 2006).

DNA detected by PCR in a sample can be interpreted in the clinical context and a positive result in an asymptomatic dog could be considered as a possible subclinical carrier that sheds the bacteria in the urine. In this sense, serological testing for canine leptospirosis is complicated because dogs may be actively infected and shedding organisms, and yet be seronegative and clinically normal (Harkin et al $2003^{\mathrm{a}}$ ). It is difficult to correlate serological findings with chronic infections and leptospiuria, which were reported in the presence of relatively low antibody titres (Rojas et al 2010). Harkin et al $\left(2003^{b}\right)$ reported that although serologic studies may provide an estimate of the exposure rate of the dogs, they do not provide information on how many dogs are actively shedding leptospires. In their study with 500 samples of dogs, using PCR as the reference test, MAT had a sensitivity of $22 \%$ and a specificity of $79 \%$ regarding the risk of shedding leptospires in the urine, which represent a low accuracy of the test. Urine bacteriological culture was also performed, but none sample were positive. Therefore, PCR appears to have more applicability in defining potential zoonotic risk of leptospirosis.

Whenit comes to recommending a diagnostic test for the diagnosis of leptospirosis in dogs, McBride et al (2007) noted that the selection of an assay relied more on the availability, cost and the feasibility of implementing the test for point-of-care diagnosis. A good test needs to discriminate between leptospirosis and a broad range of diseases that have similar presentations (Dey et al 2007). Each of the diagnostic procedures for detection of leptospires or for antibodies against them has a number of advantages and disadvantages. Some of the assays suffer from a lack of sensitivity and others are lacking specificity (Bolin 1996). The MAT and PCR are the two techniques allowing the confirmation of the diagnosis, but the MAT is only used in few reference laboratories and PCR on blood samples is possible only for a short window (few days in the first 
week of the disease (Picardeau 2013)). Therefore, no single technique can be recommended for use in a clinical situation and the use of a combination of test allows the best chances in establishing the diagnosis by obtaining the maximum diagnostic sensitivity and specificity (Bolin 1996). Thus, there is an urgent need to develop new diagnostic test that are especially user-friendly, as well as there is a need for the rapid detection of antibodies or antigens in the acute stage of the disease (Picardeau 2013).

Early diagnosis of leptospirosis is essential because it prompts a specific treatment, which is important to ensure the cure (Dey et al 2007). Treatment should be started as early as possible and preferably before the fifth day after the onset of clinical signs (Van de Maele et al 2008). Administration of appropriate antimicrobials can decrease the duration of clinical signs and urine shedding (Guerra 2009). Penicillin and its derivates are the antibiotics of choice for the treatment of leptospiremia in dogs: ampicillin or preferably amoxicillin in doses of $22 \mathrm{mg} / \mathrm{kg} \mathrm{PO} /$ SC/IV every 8 or 12 hours (Hartmann and Greene 2002) or penicillin $\mathrm{G}$ in a dose of 25,000 to $40,000 \mathrm{U} / \mathrm{kg} \mathrm{IM} /$ SC/IV every 12 hours (Sessions and Greene 2004 ${ }^{\text {b }}$. To eliminate the carrier state, tetracyclines, aminoglucosides and derivates of erythromicyn can be used, but doxycyclin is the antibiotic of choice in a dose of $5 \mathrm{mg} / \mathrm{kg}$ PO every 12 hours for 14 days (Hartmann and Greene 2002).

Supportive therapy in dogs depends on the severity of clinical signs, whether there is renal or hepatic dysfunction and other complicating factors. Dogs that recover from leptospirosis may have permanent renal dysfunctions that require life-long therapy. However, clinical recovery of canine leptospirosis may be complete. Nevertheless, all recovered patients should be monitored closely for at least 6 to 12 months after therapy, for development of complications associated with chronic renal failure (Sessions and Greene 2004 ${ }^{\mathrm{b}}$ ).

\section{LEPTOSPIROSIS IN CATS}

The first isolation of leptospires from a cat was reported in 1938 in Indonesia by Martens (Murphy 1957). Published reports of isolation of leptospires from urine or kidneys of felines clinically suspected or with leptospirosis are scarce (Larsson et al 1985). However, it has been established that these animals may harbor the bacteria in the carrier state for long periods, for example, in the blood and urine as late as the $8^{\text {th }}$ week of infection, therefore the transmission to other hosts may be facilitated by leptospiuria (Carlos et al 1971). Larsson et al (1985) studied 10 adult cats experimentally infected and detected a serologic response for 8 to 12 weeks, and the elimination of leptospires through urine was observed in cats infected with serovar Canicola beginning 2 to 4 weeks after inoculation and lasting for 2 to 8 weeks.

Cats may be incidental hosts of a variety of serovars of Leptospira which are prevalent in wildlife or domestic animals. Predator chain transmission of serovars Ballum and Icterohaemorragiae is thought to occur from rodents to felines (Bolin 1996). There are few studies about leptospirosis in cats and these show different seroprevalence rates and serotypes (Jamshidi et al 2009). Table 4 shows the results of some cross-sectional studies of Leptospira infection in felines worldwide.

The survival of leptospires for several days in murine renal tissue may indicate that felines that hunt mice could have a high risk of exposure to infection. Outdoor cats generally have higher antibody titres and transmission from rodents is more likely than in indoor animals (Arbour et al 2012). Young animals could be more vulnerable to the disease as they are reported to be more seriously affected than adults (Bolin 1996). In addition, felines could well be exposed to leptospires excreted by wildlife or present in urine of cohabiting dogs (Langston and Heuter 2003) and in rural areas cats may be exposed directly or indirectly to leptospires transmitted by peridomestic rodents or infected livestock (Everard et al 1979). In a study in Greece, Mylonakis et al (2005) reported that outdoor lifestyle of the cats and the contact with potential reservoir hosts was not associated with serovar specific seroreactivity, which raises suspicion that there is other reservoir host or transmission patterns in Leptospira infection in felines. These authors also indicate that the role of cat's characteristics such as age, sex, breed, lifestyle or the contact with reservoir hosts as potential risk factors for the infection have not been largely investigated in observational studies. Markovich et al (2012) add that the role of age, sex, breed in the disease epidemiology has not received much attention, therefore there is an urgent need for further research.

Leptospirosis in felines is not significantly different in its clinical course from the disease in dogs (Faine 1994). A specific disease syndrome in the cat is difficult to recognise or occurs most infrequently (Agunloye and Nash 1996). In a study performed in France, cats that belonged to an owner of dogs suffering from leptospirosis tested seropositive, but did not show clinical signs (André-Fontaine 2006). Clinical signs are usually mild or unapparent, despite the presence of leptospiremia and leptospiuria and histological evidence of renal and hepatic inflammation. However, the clinical manifestations that have been reported include fever during 3 to 4 days, meningitis, eye alterations, abdominal pain, vomiting, anorexia, lung disorders, bleeding in the mouth, pharyngitis, gastroenteritis, nephritis and reproductive disorders. Infections could be self-limiting in just 7 days. There is little or no information about effective treatment against leptospirosis in domestic cats (Sparkes et al 1995).

Confirmation of the diagnosis of leptospirosis in cats is difficult (Sparkes et al 1995). Shophet (1979) noted that in felines, serological techniques alone sometimes are not sufficient to confirm a leptospiral infection because with some serovars, animals may shed the organisms in their urine without having a detectable serological titre or they may respond to infection with low antibody titres that tends to decline rapidly. It has been suggested that a 
Table 4. Prevalence of Leptospira infection and frequently reported serovars in cats in cross-sectional studies carried out in some countries. países.

Prevalencia de la infección por Leptospira y serovares frecuentemente reportados en gatos en estudios transversales realizados en algunos

\begin{tabular}{|c|c|c|c|c|c|c|}
\hline \multirow[t]{2}{*}{ Author(s) } & \multirow[t]{2}{*}{ Country } & \multirow[t]{2}{*}{ City/ region } & Sample & $\begin{array}{c}\text { No } \\
\text { positive }\end{array}$ & Prevalence & \multirow[t]{2}{*}{ Most frequent serovars } \\
\hline & & & size & cats* & $(\%)$ & \\
\hline Agunloye and Nash (1996) & Scotland & Glasgow & 87 & 8 & 9.2 & $\begin{array}{l}\text { Hardjo, Icterohaemorragiae, } \\
\text { Autumnalis }\end{array}$ \\
\hline Dickenson and Love (1993) & Australia & South- eastern & 59 & 10 & 16.9 & $\begin{array}{l}\text { Pomona, Copenhageni, } \\
\text { Grippotyphosa, Tarassovi }\end{array}$ \\
\hline Higgins and Cayouette (1978) & Canada & Quebec & 19 & 0 & 0 & NA \\
\hline Jamshidi et al (2009) & Iran & Theran & 111 & 30 & 27.0 & $\begin{array}{l}\text { Hardjo, Pomona, Canicola, } \\
\text { Icterohaemorragiae, } \\
\text { Grippotyphosa }\end{array}$ \\
\hline Larsson et al (1984) & Brazil & Sao Paulo & 172 & 22 & 12.8 & Pomona, Icterohaemorragiae \\
\hline Mosallanejad et al (2011) & Iran & Ahvaz & 102 & 5 & 4.9 & Ballum \\
\hline Murphy et al (1957) & USA & Pennsylvania & 350 & 17 & 4.9 & Autumnalis, Sentot \\
\hline Mylonakis et al (2006) & Greece & Thessaloniki & 99 & 33 & 33.3 & $\begin{array}{l}\text { Rachmati, Bratislava, Ballum, } \\
\text { Bataviae }\end{array}$ \\
\hline Parreira et al (2010) & Brazil & Goiania & 330 & 23 & 6.9 & $\begin{array}{l}\text { Cynopteri, Djasiman, Butembo, } \\
\text { Castellonis, Patoc }\end{array}$ \\
\hline Shophet (1979) & New Zealand & $\ldots$ & 225 & 20 & 8.8 & $\begin{array}{l}\text { Hardjo, Pomona, Ballum, } \\
\text { Copenhageni }\end{array}$ \\
\hline
\end{tabular}

${ }^{*}$ The diagnostic test used in all studies was the MAT.

MAT titre of 1:100 or greater is an indication of Leptospira infection, but there is a lack of studies to support this and testing of paired samples to show seroconversion or an increase in titre might be essential. Other diagnostic tests described in felines are histopathology of kidney tissue and bacteriological culture of urine or tissue samples (Sparkes et al 1995).

Further studies are needed to obtain more information about the different serovars infecting cats, their reservoirs in the environment and the role of this species in the transmission of infection (Jamshidi et al 2009). Investigations on the presence of Leptospira antibodies in domestic cats will be useful for monitoring of the health of companion animals and to expand the knowledge of the disease (Parreira et al 2010).

\section{ZOONOTIC IMPLICATIONS OF LEPTOSPIROSIS IN DOGS AND CATS}

In humans, worldwide incidences of leptospirosis has been estimated in 0.1-1 cases per 100,000 inhabitants per year in geographic areas with temperate climate, to $>$ 10 cases per 100,000 inhabitants in humid (sub) tropical areas and $>100$ cases per 100,000 inhabitants affected during outbreaks (Hartskeerl et al 2011). In Chile, human leptospirosis has been reported as single cases or epidemic outbreaks, but their incidence is unknown because until a few years ago it was not considered as a reportable disease
(Dabanch 2003). In 2002, leptospirosis was declared a disease of "immediate notification" (MINSAL 2009) and Leptospira spp was classified as an infectious agent with laboratory surveillance (MINSAL 2004).

The epidemiologic importance of any specific animal species in the presentation of leptospirosis is related to local ecology, the human activities in that environment and dynamism in the prevalence and virulence of leptospires (Guerra 2009). In this sense, human infections of leptospirosis can be acquired by veterinarians, farmers, animal caretakers, animal researchers and by people exposed to contact with pet dogs or domestic livestock during daily activities (Langston and Heuter 2003).

Ocupation is a substantial risk factor as most leptospiral infections in farmers, veterinarians, abbatoir workers and meat inspectors occur by direct contact with infected animals (Bartmettler et al 2011). The risk of ocupational transmission of Leptospira has been well documented among large animal practitioners but less among small animal veterinarians (Baer et al 2009). A study carried out in Switzerland on 91 people from the professional staff of a veterinary hospital, who had been exposed to dogs with acute leptospirosis, reported no seroreactivity to the infection suggesting that zoonotic transmission could be uncommon when preventive measures for the handling of infected animals are taken (Barmettler et al 2011). On the other hand, a sample of 136 veterinary students exposed to their pets (dogs, cats, birds, hamsters, fish or turtles) in 
Spain, showed a seroprevalence of leptospiral antibodies of 20.58\% (Simón et al 1999). This report suggests that pet ownership could be related with a serological reaction to Leptospira infection and highlight the potential of zoonotic infection.

Pet ownership has actually been considered a risk factor for Leptospira infection (Guerra 2009), but there is very limited information about this. In one study in California, USA, the exposure type was pet-related in $10 \%$ of 61 leptospirosis human cases registered between 1982 and 2001 (Meites et al 2004).

It is known that domestic dogs are important reservoirs of infection for humans because they can shed live bacteria in the urine for months with no clinical signs (Batista et al 2004), and especially in urban areas dogs should be considered as an important risk factor for leptospirosis (Rodriguez et al 2004). However, the extent of human leptospirosis acquired from dogs remains undetermined. Therefore, the best way to highlight the importance of the disease is to provide the public with information about the risk of acquiring the disease and maintain a constant awareness of their specific characteristics (Levett 2001).

In cats, despite the low seroprevalence, L. interrogans is a public health concern due to contact between cats and humans, which provides a link between an environmental reservoir and humans (Mosallanejad et al 2011). There is no evidence to suggest that cats are less capable of transmitting leptospirosis than dogs, but the characteristic squatting posture that cats assume when they urinate and the fact that they cover the urine, could limit the chances of prolonged survival of the organism (Everard et al 1979). However, due to the lack of visible symptomatic manifestations and the relatively long leptospiuria even with the presence of high antibody titres, domestic cats should be considered as a potential source of infection for humans and other domestic animals (Larsson et al 1985).

\section{PREVENTION OF LEPTOSPIROSIS}

In order to control leptospirosis in dogs, vaccination is considered to be the frontline defense against the disease and its objective is to prevent leptospiremia and urinary shedding as well as to reduce the severity of the clinical signs (Van de Maele et al 2008). Since the control of shedding of leptospires by wild animal reservoirs is impossible, vaccination of dogs that live in endemic areas is essential.

Canine vaccines generally contain $L$. interrogans serovars Canicola and Icterohaemorragiae, although recently developed vaccines may also include $L$. interrogans serovar Pomona and L. kirshneri serovar Grippotyphosa (Adler and De la Peña Moctezuma 2010). However, the increasing epidemiological evidence that other serovars are involved in clinical infections highlights the emerging need to produce new and multivalent Leptospira vaccines (Wilson et al 2013a).
Immunization protects against disease caused by the homologous or antigenically similar serovars and the antibodies produced are relatively serovar-specific (Levett 2001). Vaccinal protection against Leptospira involves neutralising antibodies target to the proteins or carbohidrates in the external envelope of the bacterium. Given the specific response to a serovar, the heterologous protection of the current vaccines is incomplete (Greene and Schultz 2008). For this reason, dog owners should be aware that their pets may not be fully protected because serovars that cause the disease may vary temporally and geographically (Guerra 2009).

In response to vaccination against Leptospira infection, Bolin (1996) indicated that while most dogs develop relatively low antibody titres (from 1:100 to 1:400) that persist at these levels for 1 to 3 months after application of the vaccine, some animals develop high titres after vaccination, which decline in longer times. Klaasen et al (2003) observed that the antibody response against a bivalent inactivated vaccine (containing serovars Canicola and Icterohaemorragiae) may persist up to 12 months after vaccination depending on the application protocol used. Another study carried out in Europe, reported that a multivalent vaccine called DHPPi/L4R containing serovars Canicola, Icterohaemorragiae, Bratislava and Grippotyphosa was applied to six weeks old puppies and induced an immunity, which after two vaccinations was still effective for up to one year (Wilson et al 2013 ${ }^{\mathrm{a}}$ ). This vaccine also protected from development of clinical disease and sheeding after challenge (Wilson et al 2013 ${ }^{\mathrm{b}}$ ).

To induce an effective immunity with Leptospira vaccines, a minimum of 3 doses applied 3 or 4 weeks apart is recommended, with annually booster vaccinations and even biannually for animals in an endemic region (Langston and Heuter 2003). For dogs at-risk (with the understanding that dogs at-risk can vary geographically), annual vaccination with multivalent vaccines that include 4 serovars is recommended. Furthermore, canines that have recovered from leptospirosis might need an annual vaccination because such dogs could be at risk of exposure and it is unknown if life-long immunity after natural infections actually occurs (Sykes et al 2011).

Anaphylactic reactions (manifested as facial edema, pruritus, hypotension or dyspnea) could occur with Leptospira vaccines, especially in small breed dogs, such as miniature dachshunds (Sessions and Greene 2004 ). Although such reactions may occur in any breed, the prevalence of side-reactions are decreasing and their rate might be similar to those induced by vaccines for other pathogens (Sykes et al 2011).

Regarding pharmacological imunoprophilaxis, appropriate antibiotics are highly effective in preventing urinary shedding of the bacteria (Brown and Prescott 2008). Treatment of other dogs in the households that may have been coincidentally exposed to leptospires in the environment is recommended with antibiotics like doxycycline, 
and ideally with monitoring of acute and convalescent phase leptospiral antibody titres (Sykes et al 2011).

Wild animal reservoirs and animals with subclinical infection continue to harbor and shed leptospires, therefore, rodent control in shelters, maintenance of environmental conditions to prevent the bacterial survival and isolation of infected animals are important steps to prevent the spread of infection. Prevention should start by limiting contact of dogs with wild animal reservoirs as well as contaminated water (Goldstein 2010).

Veterinarians should be cautious in animals with renal disease (Sykes et al 2011) and they can minimise the risk of occupational transmission by following recommended infection control practices (Baer et al 2009). Contact with urine and other body fluids from infected animals or animals with a high index of suspicion of leptospirosis should be avoided through the use of gloves. Additional equipment such as masks and protective eyewear should be worn when performing activities that can cause splashes and hands should be washed thoroughly with soap and water after handling or cleaning up infected animals (Guerra 2009). Disposable bedding should be placed in biohazard bags and properly handled. In addition, the movement of dogs suspected to have leptospiosis should be minimized and areas of contact should be disinfected (Sykes et al 2011).

Leptospires are susceptible to UV radiation, desiccation and routine disinfectants (Sykes et al 2011). Iodine or chlorine based disinfectants may be used to clean contaminated cages and surfaces (Guerra 2009) but accelerated hydrogen peroxide and quaternary ammonium solutions are also effective (Sykes et al 2011).

Raising awareness of the disease and methods of prevention is recommended by the WHO (2006) to prevent the risk of exposure and transmission of the disease. Upon diagnosis of leptospirosis, veterinarians should inform the owners of their zoonotic potential and recommend that they seek medical attention if illness occurs around the time their dog is diagnosed. Also, immunocompromised humans should be referred to their medical practitioner for advice about the disease (Sykes et al 2011). Children and pregnant women should keep away from the animal while it is being treated. Futhermore, owners should be advised that if their pet is infected, they should avoid contact with urine, feces or saliva, they should wear protective clothing, clean surfaces that may be contaminated and they have to make ensure that their pets receives the full course of antibiotic treatment (Brown and Prescott 2008).

Dogs may be sentinels for human exposure to leptospires (Moore et al 2006). The knowledge of the prevalent serovars and their maintenance hosts is important for understanding the transmission of the bacteria in the area (Levett 2001), which will help to confront the disease more efficiently as the clinical suspicion will be more accurate and the therapeutic and preventive measures more appropriate (Riedemann and Zamora 1987). Predicting the occurrence of leptospirosis is also potentially valuable as it serves to reduce the exposure of pet owners to sources of leptospires contacted by their pets (Ward 2002). The identification of infective Leptospira serovars allows veterinarians to consider and pass information to the owners about possible reservoir hosts and the potential of immunoprophylaxis against specific serovars (Gautam et al 2010 ${ }^{\mathrm{b}}$ ).

\section{CONCLUSIONS}

Leptospirosis has a complex epidemiology in which a variety of domestic and wild animal species are involved. Dogs and cats can be infected with different serovars, which vary according to the geographic area, environmental characteristics, the degree of contact with the reservoir hosts of the bacteria and the life conditions of the pets.

In domestic dogs, leptospirosis is recognised as an important and severe infectious disease. Detailed information on the spread and distribution of the infection is important for the instigation of control measures and to increase awareness among pet owners and veterinarians. Leptospirosis is not always diagnosed or considered as a differential diagnosis of other pathologies in canine clinical practice, mostly due to their variable clinical presentation, which might result in variable prevalence rates between different regions and countries.

In cats, there is very little information about leptospirosis, particularly of the specific disease characteristics, the clinical utility of diagnostic tests and treatment options. As a result, only limited data on the epidemiology of the infection in feline populations is available. However, the disease does occur in this species and should be considered in feline clinical practice.

The potential of zoonotic transmission of the Leptospira infection from dogs and cats to their owners does exists due to the renal shedding of the bacteria in both species and the close contact between humans and their pets, but the true extent or significance has still not been investigated with accuracy.

To prevent the disease in pets and their owners, simple preventive measures can be applied focusing on reducing the chances of infection, including vaccination in dogs, good hygiene and to avoid the exposure of dogs and cats to infected animals and reservoir hosts.

Further studies are needed to determine the characteristics of the Leptospira infection in different canine and feline populations and also it is necessary to increase the awareness of leptospirosis in veterinarians and through them, pass it to pet owners and the general public.

\section{REFERENCES}

Acha P, B Szyfres. 2003. Leptospirosis. En: Acha P, Szyfres B (eds). Zoonosis y enfermedades transmisibles comunes al hombre y a los animales. OPS/OMS, Washington, USA, Pp 175-186.

Adler B, A De la Peña Moctezuma. 2010. Leptospira and leptospirosis. Vet Microbiol 140, 287-296.

Agunloye CA, A Nash. 1996. Investigation of possible leptospiral infection in cats in Scotland. J Small Anim Pract 37, 126-129. 
Ambily R, M Mini, S Joseph, S Krishna, G Abhinay. 2012. Canine leptospirosis- a seroprevalence study from Kerala, India. Vet World $6,42-44$.

Ananda KJ, T Suryananarayana, P Sharada, P D'Souza. 2008. Diagnosis and treatment of leptospirosis in a dog. A case report. Vet World $1,278-279$

André-Fontaine G. 2006. Canine leptospirosis- Do we have a problem? Vet Microbiol 17, 19-24.

André-Fontaine G, J Hernandez. 2008. Leptospirosis in dogs. Point Veterinaire 39, 47.

Arbour J, Blais MC, Carioto L, Sylvestre D. 2012. Clinical leptospirosis in three cats (2001-2009). J Am Anim Hosp Assoc 48, 256-260.

Aslantas O, V Ozdemir, S Kilic, C Babur. 2005. Seroepidemiology of leptospirosis, toxoplasmosis and leishmaniosis among dogs in Ankara, Turkey. Vet Parasitol 129, 187-191.

Baer R, W Turnberg, D Yu, R Wohrle. 2009. Leptospirosis in a small animal veterinarian: reminder to follow standarized infection control procedures. Zoonoses Public Health 57, 281-284.

Barmettler R, A Schweighauser, S Bigler, AM Grooters, T Francey. 2011. Assessment of exposure to Leptospira serovars in veterinary staff and dog owners in contact with infected dogs. J Am Vet Med Assoc 238, 183-188.

Batista C, S Azevedo, C Alves, S Vasconcellos, Z Morais, I Clementino, S Lima, J Neto. 2004. Seroprevalence of leptospirosis in stray dogs from Patos City, State of Paraíba, Brazil. Braz J Vet Res Anim Sci 41, 131-136.

Bharti A, J Nally, J Ricaldi, M Mathias, M Lovett, P Levett, R Gilman, M Willing, E Gotuzzo, J Vinetz. 2003. Leptospirosis: a zoonotic disease of global importance. Lancet Infect Dis 3, 757-772.

Bolin CA. 1996. Diagnosis of leptospirosis: a reemerging disease of companion animals. Semin Vet Med Surg 11, 166-171.

Brown K, J Prescott. 2008. Leptospirosis in the family dog: a public health perspective. Can Med Assoc J 178, 399-401.

Burriel A, C Dalley, M Woodward. 2003. Prevalence of Leptospira among farmed and domestic animals in Greece. Vet Rec 153, 146-148.

Carlos E, W Kundin, R Watten, C Tsai, S Irving, ET Carlos, A Directo. 1971. Leptospirosis in the Phillipines: feline studies. Am J Vet Res $32,1455-1456$.

Cerqueira G, M Picardeau. 2009. A century of Leptospira strain typing. Infect Genet Evol 9, 760-768.

Dabanch J. 2003. Zoonosis. Rev Chil Infect 20, 47-51.

Dey S, C Madhan-Mohan, R Ramadass, K Nachimuthu. 2007. Recombinant antigen-based dipstick ELISA for the diagnosis of leptospirosis in dogs. Vet Rec 160, 186-188.

Dickeson D, D Love. 1993. A serological survey of dogs, cats and horses in south-eastern Australia for leptospiral antibodies. Aust Vet $J$ 70, 389-390.

Everard C, E Cazabon, D Dreesen, C Sulzer. 1979. Leptospirosis in dogs and cats on the island of Trinidad: West Indies. Int J Zoon 6, 33-40.

Faine S. 1994. Leptospira and leptospirosis. CRS Press, Florida, USA.

Fonzar U, H Langoni. 2012. Geographic analysis on the recurrence of human and canine leptospirosis in the city of Maringá, State of Paraná, Brazil. Rev Soc Bras Med Trop 45, 100-105.

Gautam R, L Guptill, C Wung, A Potter, G Moore. 2010a. Spatial and spatio-temporal clustering of overall and serovar-specific leptospira Microscopic Agglutination Test (MAT) seropositivity among dogs in the United States from 2000 through 2007. Prev Vet Med 96, 122-131.

Gautam R, C Wung, L Guptill, A Potter. 2010 ${ }^{\mathrm{b}}$. Detection of antibodies against leptospira serovars via microscopic aglutination test in dogs in the United States, 2000-2007. J Am Vet Med Assoc 237, 293-299.

Ghneim G, J Viers, B Chomel, P Kass, D Descollonges, M Johnson. 2007. Use of case-control study and geographic information systems to determinate environmental and demographic risk factors for canine leptospirosis. Vet Res 38, 37-50.

Goldstein R, R Lin, C Langston, P Scrivani, H Erb, S Barr. 2006. Influence of infecting serogroup on clinical features of leptospirosis in dogs. J Vet Intern Med 20, 489-494.
Goldstein R. 2010. Canine leptospirosis. Vet Clin Small Anim 40, 1091-1101. Greene C, R Schultz. 2008. Inmunoprofilaxis. En: Greene C (ed). Enfermedades infecciosas del perro y el gato. Intermédica, Buenos Aires, Argentina.

Greene C, J Sykes, C Brown, K Hartmann. 2008. Leptospirosis. En: Greene $\mathrm{C}$ (ed). Enfermedades infecciosas del perro y el gato. Intermédica, Buenos Aires, Argentina, Pp 448-463.

Guerra M. 2009. Leptospirosis. J Am Vet Med Assoc 234, 472-477.

Harkin K, Y Roshto, J Sullivan. 2003 a Clinical application of a polymerase chain reaction assay for diagnosis of leptospirosis in dogs. $\mathrm{J} \mathrm{Am} \mathrm{Vet}$ Med Assoc 222, 1224-1229.

Harkin K, Y Rostho, J Sullivan, T Purvis, M Chengappa. 2003b . Comparison of polymerase chain reaction assay, bacteriologic culture, and serologic testing in assessment of prevalence of urinary shedding of leptospires in dogs. J Am Vet Med Assoc 222, 1230-1234.

Hartmann K, C Greene. 2002. Enfermedades provocadas por infecciones bacterianas sistémicas: leptospirosis. En: Ettinger S, Feldman E (eds). Tratado de Medicina Interna Veterinaria: enfermedades del perro y del gato. Elsevier, Madrid, España, Pp 616-619.

Hartskeerl R, M Collares-Pereira, A Ellis. 2011. Emergence, control and re-emerging of leptospirosis: dynamics of infection in the changing world. Clin Microbiol Infect 17, 494-501.

Higgins R, P Cayouette. 1978. Serological diagnosis of leptospirosis in the Province of Quebec. Can Vet J 19, 13-16.

Iwamoto E, Y Wada, Y Fujisaki, S Umeki, M Jones, T Mizuno, K Itamoto. 2009. Nationwide survey of Leptospira antibodies in dogs in Japan: results from microscopic agglutination test and enzime-linked immunoabsorvent Assay. J Vet Med Sci 71, 1191-1199.

Jamshidi S, M Akahavizadegan, S Bokaie, N Maazi, A Ghorban. 2009. Serologic study of feline leptospirosis in Theran, Iran. Iran J Microbiol 1, 32-36.

Klaasen H, M Molkenboer, M Vrijenhoek, M Kaashoek. 2003. Duration of immunity in dogs vaccinated against leptospirosis with a bivalent inactivated vaccine. Vet Microbiol 95, 121-132.

Ko A, C Goarant, M Picardeau. 2009. Leptospira, the dawn of the molecular genetics for an emerging zoonotic pathogen. Nat Rev Microbiol 7, 736-748.

Langston C, K Heuter. 2003. Leptospirosis, a re-emerging zoonotic disease. Vet Clin Small Anim 33, 791-807.

Larsson C, C Santa Rosa, M Hagiwara, G Paim. 1984. Prevalence of feline leptospirosis: serologic survey and attemps of isolation and demostration of the agent. Int J Zoon 11, 161-169.

Larsson C, C Santa Rosa, M Matiko, E Birgel, W Fernandes, G Paim. 1985. Laboratory and clinical features of experimental feline leptospirosis. Int J Zoon 12, 111-119.

Lau C, L Smythe, S Craig, P Weinstein. 2010. Climate change, urbanisation and leptospirosis: fuelling the fire?. T Roy Soc Trop Med H 104, 631-638.

Levett P. 2001. Leptospirosis. Clin Microbiol Rev 14, 296-326.

Levett P. 2004. Leptospirosis: a forgotten zoonosis?. Clin Applied Immunol $\operatorname{Rev} 4,435-448$.

Markovich JE, L Ross, E McCobb. 2012. The prevalence of leptospiral antibodies in free roaming cats in Worcester County, Massachusetts. $J$ Vet Intern Med 26, 688-689.

McBride A, B Santos, A Queiroz, A Santos, R Hartskeerl, M Reis, A Ko. 2007. Evaluation of four whole-cell Leptospira-based serological test for diagnosis of urban leptospirosis. Clin Vaccine Immunol 14, 1245-1248.

Meeyam T, P Tablerk, B Petchanok, D Pichpol, P Padungtog. 2006. Seroprevalence and risk factors associated with leptospirosis in dogs. Southeast Asian J Trop Med Public Health 37, 148-153.

Meites E, M Jay, S Deresinski, W Shieh, S Zaki, L Tompkins, D Smith. 2004 Reemerging Leptospirosis, California. Emerg Infec Dis 10, 407-412.

Miller R, S Ross, N Sullivan, N Perkins. 2007. Clinical and epidemiological features of canine leptospirosis in North Queensland. Aust Vet $J$ 85, 13-19.

MINSAL, Ministerio de Salud, Chile. 2004. Reglamento sobre notificación de enfermedades transmisibles de declaración obligatoria. Decreto $\mathrm{N}^{\circ} 158,22$ de octubre de 2004. 
MINSAL, Ministerio de Salud, Chile. 2009. Circular de vigilancia y control de leptospirosis. Circular $\mathrm{N}^{\circ}$ B51/10, 6 de febrero de 2009.

Mosallanejad B, Ghorbanpoor, R Avizeh, R Abdollapour, K Abadi. 2011 A serological survey of leptospiral infection of cats in Ahvaz, south western of Iran. Int J Vet Res 5, 49-52.

Moore G, L Guptill, N Glickmann, R Caldanaro, D Aucoin, L Glickmann. 2006. Canine leptospirosis, United States, 2002-2004. Emerg Infect Dis 12, 501-503.

Murphy L, T Cardeilhac, J Carr. 1957. The prevalence of leptospiral agglutinins in the sera of the domestic cat. Cornell Vet 48, 3-9.

Mylonakis M, E Bourtzi-Hatzopoulou, AF Koutinas, E Petridou, M Saridomichelakis, L Leontides, A Siochu. 2005. Leptospiral seroepidemiology in a feline hospital population in Greece. Vet Rec 156, 615-616.

O'Keefe J, J Jenner, N Sandifer, A Antony, N Williamson. 2002. A serosurvey for antibodies to Leptospira in dogs in the lower North Island of New Zealand. New Zeal Vet J 50, 23-25.

Parreira I, V Jayme, E Walburga, L Guimaráes, D De Abreu. 2010. Epidemiological features of infection through Leptospira spp in domestic cats (Felis catus) apparently healthy within the metropolitan area of Goiania, Brazil. Enciclopédia Biosfera 6, 1-5.

Paul-Pierre P. 2009. Emerging diseases, zoonoses and vaccines to control them. Vaccine 27, 6435-6438.

Picardeau M. 2013. Diagnosis and epidemiology of leptospirosis. Méd Maladies Infect 43, 1-9.

Picardeau M, E Bertherat, M Jancloes, A Skouloudis, K Durski, R Hartskeerl. 2013. Rapid tests for diagnosis of leptospirosis: current tools and emerging technologies. Diagn Micr Infec Dis doi: 10.1016/j.diagmicrobio.2013.09.012.

Pineda M, J López, M García. 1996. Frecuencia de leptospirosis en perros al test de aglutinación microscópica en Chillán-Chile. Arch Med Vet 28, 59-66.

Rad M, Zeinali A, V Yousofi, A Tabatabayi, S Bokaie. 2004. Seroprevalence and bacteriological study of canine leptospirosis in Theran and itssuburban areas. Iran J Vet Res 5, 73-80.

Ribeiro de Castro J, S Sampaio, M Assuncão de Souza, A Correia. 2011. Predominant Leptospira spp serovars in serological diagnosis of canines and humans in the city of Uberlandia, State of Minas Gerais, Brazil. Rev Soc Bras Med Trop 44, 217-222.

Riedemann S, J Zamora. 1987. Leptospirosis animal. Serogrupos y serovares presentes en Chile y su importancia. Arch Med Vet 19, 69-72.

Roach J, M Van Vuuren, J Picard. 2010. A serological survey of antibodies to Leptospira species in dogs in South Africa. S Afr Vet Ass 81, 156-159.

Rodríguez A, B Ferro, M Varona, M Santafé. 2004. Evidencia de exposición a Leptospira en perros callejeros de Cali. Biomédica 24, 291-295.

Rojas P, A Monahan, S Schuller, L Miller, B Markey, J Nally. 2010. Detection and quantification of leptospires in urine of dogs: a maitenance host for the zoonotic disease leptospirosis. Eur J Clin Microbiol Infect Dis 29, 1305-1309.

Safiullah S, A Abu Saleh, S Munwar. 2009. Laboratory methods for diagnosing leptospirosis: a review. Bangladesh J Med Microbiol 3, 39-43.
Sessions J, C Greene. 2004a ${ }^{\mathrm{a}}$. Canine leptospirosis: epidemiology, pathogenesis and diagnosis. Comp Cont Educ Pract Vet 26, 606-618.

Sessions J, C Greene. 2004 ${ }^{\mathrm{b}}$. Canine leptospirosis: treatment, prevention and zoonosis. Comp Cont Educ Pract Vet 26, 700-705.

Shi D, M Liu, S Guo, S Liao, M Sun, J Liu, L Wang, Z Wang, S Wang, D Yang, T Chai. 2012. Serological survey of canine leptospirosis in southern China. Pak Vet J 32, 280-282.

Silva R, S Riedemann. 2007. Seroprevalencia de leptospirosis canina en perros atendidos en clínicas veterinarias mediante Aglutinación Microscópica y comparación con las técnicas de aislamiento e inmunofluorescencia indirecta. Arch Med Vet 39, 269-274.

Simón M, C Ortega, JL Alonso, O Gironés, L Muzquiz, J García. 1999. Risk factors associated with the seroprevalence of leptospirosis among students at the veterinary school of Zaragoza University. Vet Rec 144, 287-291

Shophet R. 1979. A serological survey of leptospirosis in cats. NZ Vet J 27, 244-246.

Sontas B, F Kaysigiz, H Ekici. 2012. Methods of oestrus prevention in dogs and cats: a survey of Turkish veterinarian's practices and beliefs. Arch Vet Med 44, 155-166.

Sparkes A, A Wolf, J Wills. 1995. Enfermedades infecciosas: leptospirosis. En: Wills J, Wolf A (eds). Manual de medicina felina. Acribia, Zaragoza, España.

Stokes J, J Kancene, WD Schall, J Kruger, RA Miller, L Kaiser, C Bolin. 2007. Prevalence of serum antibodies against six leptospira serovars in healty dogs. J Am Vet Med Assoc 230, 1657-1665.

Sykes J, K Hartmann, K Lunn, G Moore, R Stoddard, R Goldstein. 2011. 2010 ACVIM small animal concensus statement on leptospirosis: diagnosis, epidemiology, treatment and prevention. $J$ Vet Intern Med 25, 1-13.

Van de Maele I, A Claus, F Haesebroukc, S Daminet. 2008. Leptospirosis in dogs: a review with emphasis on clinical aspects. Vet Rec 163, 409-413.

Vijayachari P, A Sugunan, N Shriram. 2008. Leptospirosis: an emerging global public health problem. J Biosci 33, 557-569.

Ward M. 2002. Clustering of reported cases of leptospirosis among dogs in the United States and Canada. Prev Vet Med 56, 215-226.

WHO, World Health Organization. 2006. Guidelines to prevention and control of leptospirosis. Zoonosis division, National Institute of Communicable Diseases, Directorate General of Health Services, Delhi, India. 22-Sham Nath Marg, Delhi-110054.

Wilson S, C Stirling, A Thomas, V King, E Plevová, L Chromá, E Siedek, J Illambas, J Salt, G Sture. 2013a . A new multivalent (DHPPI/L4R) canine combination vaccine prevents infection, sheeding and clinical signs following experimental challenge with four Leptospira serovars. Vaccine 31, 3131-3134.

Wilson S, C Stirling, A Thomas, V King, E Plevová, L Chromá, E Siedek, J Illambas, J Salt, G Sture. 2013 ${ }^{\mathrm{b}}$. Duration of immunity of a multivalent (DHPPi/L4R) vaccine against four Leptospira serovars. Vaccine 31, 3126-3130.

Xue F, J Yan, M Picardeau. 2009. Evolution and pathogenesis of Leptospira spp: lessons learned from the genome. Microbes Infect 11, 328-333.

Zavitsanou A, F Babatsikou. 2008. Leptospirosis: epidemiology and preventive measures. Health Science Journal 2, 75-82. 